\title{
Governing the "Digital Shadows": Public Policy and Information Communication Technology (ICT) Acquisition and Utilization in Africa
}

\author{
Ebenezer Olatunji Olugbenga \\ Department of Political Science, Ekiti State University, Ado-Ekiti, Nigeria \\ Email:olugbenga2010@gmail.com
}

How to cite this paper: Olugbenga, E.O. (2017) Governing the "Digital Shadows": Public Policy and Information Communication Technology (ICT) Acquisition and Utilization in Africa. Open Access Library Journal, 4: e3564.

https://doi.org/10.4236/oalib.1103564

Received: March 27, 2017

Accepted: April 25, 2017

Published: April 28, 2017

Copyright (c) 2017 by author and Open Access Library Inc.

This work is licensed under the Creative Commons Attribution International License (CC BY 4.0).

http://creativecommons.org/licenses/by/4.0/

\begin{abstract}
This paper examines the challenges of appropriating the benefits of the Information Communication Technology (ICT) revolution by African states, against the backdrop of the realities of globalization and the role that ICT plays in global power relations. Built on the foundations of Jurgen Habermas' public sphere, it weaves a conceptual framework around the ideas of a "cyber-square" and "cyberspace policy" to argue for an African perspective to the adoption, acquisition and utilization of Information Communication Technology (ICT) to meet the specific needs of sub-Saharan African countries. It argues that, in spite of the challenges of ICT development in Africa, it is a lifeline that African states should embrace determinedly through purposeful public policy. It argues this deliberately to underscore the importance of purposeful ICT policy making to meet Africa's needs for social and economic revival and the promotion of the numerous national and continental interests that straddle the broad spectrums of the African political, cultural and economic landscapes. Through the use of secondary data, the author gives evidences for these by drawing examples from African countries. The paper recommends a multi-stakeholder approach to ICT policy development that reigns in not only African governments but also other stakeholders in Africa's ICT revolution. This, it argues, will help Africa evolve acceptable, adaptable and beneficial ICT policies capable of galvanizing and sustaining positive development to move Africa to its next stage of development.
\end{abstract}

\section{Subject Areas}

Politics

\section{Keywords}

"Digital Shadows", Public Policy, Information Communications Technology (ICT), "Cyber-Square”, Cyberspace, Collaborative Policymaking, Africa 


\section{Introduction}

The rapid development and global spread of Information Communications Technology (ICT) is a reality that has caught up with human societies in the twenty-first century. Whereas technological research, knowledge production, dissemination and transfer now drive international politics to a reasonable extent, states rank differently in terms of technological knowhow and Information Communications Technology (ICT) capabilities. Today, ICT capabilities can advance or hinder the attainment or otherwise of national political, economic and cultural objectives, goals or values of states. Indeed, a country's ICT capability can affect the extent to which a country can pursue and attain her national values of cultural preservation and advancement, achieve socio-political stability as well as economic recovery and advancement, depending on which side of the global technological movement the nation finds itself.

Adopting a combination of the "cybersquare" and "cyberspace policy" as conceptual framework, the paper interrogates the significant question of African states' engagement with the ICT revolution as a requirement for continental political, economic and socio-cultural renaissance. It identifies the challenges, opportunities and strides taken by African states in ICT capability and development, arguing that taking advantage of the opportunities offered by ICT is the next golden opportunity for Africa to break away from its past experiences of poverty, socio-economic exploitation and underdevelopment.

Section one introduces the paper while Section two examines the state of the ICT revolution in Africa. Section three explicates briefly, the significance of the research while Section four focuses on the conceptual framework that weaves the concepts of "cybersquare" and "cyberspace policy" into Habermas' public square to explain the relevance of ICT to the African development process. Section five presents an historical trajectory of globalization, ICT and Africa. It argues that since telecommunications serve as a catalyst for overall development by activating and making available relevant data and information for development, ICT development in Africa must necessarily be policy driven for specific ends. Thus, it presents the case for an African renaissance through ICT but warns this can become a reality soon if African governments and other stakeholders develop the capacity and exhibit the willingness to implement acceptable, people-oriented policies. Section eight highlights the major contributions of the study to scholarship and policy, its innovations and limitations. Section nine concludes the study and suggests areas for further study.

\section{The State of Information Communications Technology (ICT) Revolution in Africa}

For many African countries, the global technological movement and technological relations among states has yielded different types of outcomes as they relate and negotiate with countries of the North, who have been the main custodians and propagators of modern, western technology and culture that have attained global relevance, acceptability and dominance. 
Thus, just as there is economic differentiation and diversity between countries of the global North and South (which includes Africa), there are differences between the "technologically advanced" countries of the North and the "technologically backward" countries of the South. This is not surprising since technological knowhow and advancement has become one of the major indices of development. Countries of the North are the main producers or generators of modern technology (even if not "originators" in the strict sense of the word). This development is traceable to historical factors including "brain drain" that has evacuated much human talent and expertise from countries of the South to those of the North in search of better living and fulfillment. Thus, many (with a few exceptions like South Korea and several "Asian Tiger" countries of the South) are mainly recipients or, in the strict sense of the word, "users" of modern, Western technology.

Many African economies that display aspects of western development are merely ramparts of western capitalism mostly with assembly plants and "showrooms" for western technologies. In some African countries like South Africa and to some extent, Ghana and Nigeria, these shadows of technological advancement have altered the structure of the economy by creating two types of economies, namely the "skilled" and the "unskilled" out of the co-existence of the pre-existing (traditional) and new (mainly information technology dependent) economic structures.

In South Africa, for instance, Mbeki [1] notes that technological knowhow and technological relations have created two separate but co-existing economies: a first world or "new" (technologically driven) economy that is "advanced, sophisticated... based on skilled labour... (and is) becoming more globally competitive". The other is a "third world economy" that is mainly "informal, marginalized unskilled... populated by the unemployed and those unemployable in the formal sector". This is largely reflective of the situation in many African countries.

Taking Ghana as another example of one of the most foreign technology dependent countries in Africa, research findings indicate that, along with financial services, transport, construction and mining, communications contributed a fifth of the total increase in total factor productivity of Ghana between 1991 and 2005 [2] [3] and [4]. However, Ghana achieved that high total productivity factor temporarily in those years by changing the sectoral composition of employment away from agriculture, one of the main areas where Ghana has comparative advantage and thrived in the 1960s, to the high-tech sectors (including communications) which are mainly dependent on foreign technology.

Nigeria's experience with oil and associated technologies is also instructive. Since the discovery and exportation of crude oil shortly before Nigeria's independence, the country's development planning has revolved around oil for which purpose the country relied on foreign technology, having no indigenous technology for oil exploration, extraction, refinement and even transportation. This was at the expense of agriculture that was the backbone of the economy 
prior to the discovery of oil. Many African countries experienced dependency in different areas of development including technology. A knowledging Africa's situation of all-round (including technological) dependency as a possible contributory factor to the declining fortunes of the continent, The World Bank [5] noted that "by the 1990s, it was clear that Africa was being marginalized in the world economy, with declining world export shares, falling terms of trade, and rising indebtedness". Also, Kiely [6] also affirms this fall in Africa and Latin America's share of world trade in spite of the globalization of production. In essence, this meant that globalization had not been working in the favour of Africa.

Since information communications technology is a major global driver of overall development, it becomes important to inquire about the state of ICT development in Africa today. As the second largest but least computerized continent with a population of over 500 million, Africa was in the past left out of the "global information society" and has been described as the "lost continent" [7]. One should question how easy it would be for Africa to develop if the estimation is true that a minimum of $90 \%$ of data on Africa may reside on databases in the West? [8]. Thus, although the embrace of ICT has brought several benefits to the continent so that it plays an important part in its process of development, ICT in Africa still suffers a myriad of problems relating to procedures, purpose and most importantly, policy objectives and direction. Odedra, Lawrie, Bennet and Goodman [7] have identified these to include lack of coordination that has resulted in uneven development of Africa's IT sector; poor infrastructure and inadequate IT literacy that has promoted over-dependence on expatriate personnel for many IT solutions ranging from systems analysis, programming, maintenance, consulting for business and for e-governance to the high cost of IT equipment and lack of high speed internet connectivity in many countries. There are also the challenges of vandalization of the little available equipment.

Then, there is the overarching influence of ICT on the security of Africa's many weak, economically and technologically dependent states because in the technological age, information is power which now resides not with strongwilled tyrants and sit-tight rulers (not leaders) that dot Africa's political landscape but with the owners and custodians of technology. Thus, it can be safely said that as far as ICT in Africa is concerned, real power resides not within but outside the continent in the twenty-first century. Herein lays the importance of purposive public policy both to direct and midwife ICT development to address the specific needs of Africans rather than the economic, cultural, security and political interests of the owners and originators of ICT in Africa.

Since Africa's development efforts are currently dominated by foreign ideas and technology, many African economies experience growth without development. But there are more serious consequences for Third World countries that depend excessively on foreign technology. In African and many other Third World countries, there are several national political and cultural values which protection and preservation are affected by the "technological progress" which the embrace if ICT has helped to mediate. 
While the economies of the developed countries are often formal, ICT based, sophisticated, based on skilled labour and are global leaders in science, technology and industry, the bulk of Third World economies are characteristically informal, un-skilled, marginalized and mainly populated by the unemployed and those who are unemployable in the formal sector. For these reasons, the embrace of ICT and new skills has given birth to a "first-world" or "new" economy in Third World countries that has been polarizing their labour markets [9] [10] and [11]. According to Pejout [12], labour market polarization in Africa is explained by the skill-based technology that characterizes the "new economy" for which majority of existing labour forces in African countries are not prepared in terms of knowledge and skills. This happened at the point of embrace of ICT, the fifth historical phase of capitalist development and a follow-up to the Structural Adjustment Programme (SAP) which ended in the early 1990s.

Pejout [12] argues further that the typical relationship between the old and the new economies in Africa are sub-optimal, varying between "disconnection and a trickle-down effect". This is not surprising, given that the technological market by countries of the North is "closed" against Third World countries, because countries of the North are very reluctant to transfer technology to countries of the South, Africa inclusive. At best, they are willing to enter into economic alliances with certain countries of the South only to serve as distribution hubs for Western technology; the so-called ramparts of imperialism.

The mass media which are also products of Western technology also helps to perpetuate imperialism through dependency of developing countries on the technologically advanced countries of the North. Although this second level of imperialism has been going on for a long time, some developing countries try to work collectively to resist this using several means that include global institutions such as the United Nations Educational, Scientific and Cultural Organization (UNESCO). For example, Smith argues that:

Through UNESCO, Third World Countries try to act collectively to resist the pressures from Westernized mass media, and the cultural, educational and scientific imperialism which introduces inappropriate technology and educational values into their societies [13].

Smith argues further that the struggle to rid Third World countries of this second level of imperialism through collective action by affected countries constitutes an aspect of the anti-imperialist alliance by such countries against colonialism, neo-colonialism and racialism [9]. Yet, since many Third World countries relate with the Information Communication Technology (ICT) world mainly as recipients rather than producers or originators of technology, the extent and outcomes of ICT control within such recipient countries will be limited. For instance, although there is no proof of its correctness, western media's portrayal of Satan as a black personality and of God and His angels as white promotes in people an involuntary association of black with evil and white with good [14]. 
The Information Communication Technology (ICT) revolution is affecting African countries in several other ways. These include promotion and deepening of cultural, educational and scientific dependency in Africa through neglect and promotion of other cultures at the expense of African cultures, value systems and orientations.

Also, the (ICT) revolution is threatening political stability in Africa by rendering African states vulnerable to the activities of violent non-state actors who have access to modern, "virtual weapons" of technology in addition to physical arms and ammunition with which they effectively contest the political space with government. Such groups have the capacity to unleash on the state what Madayan [15] describes as "a worldwide franchise of terror". They do so to weaken the economies of their target states by attacking major governmental and economic installations; by discouraging foreign direct investments and by diverting resources (including hard-earned foreign exchange) away from development projects to investment in arms and ammunition that are required to successfully engage such groups in campaigns for state security, stability, survival and economic prosperity.

When such actors or groups with ethnic or religious agenda contest the political space with governments of weak, heterogeneous states (and they are common in Africa), such countries may easily become ethnically polarized, religiously divided and politically vulnerable and unstable with catastrophic outcomes for such states and their citizens. This is because projections of national cohesion are affected with consequences for national security. African examples of such technology-bolstered groups include the Al-Shabab operations in East Africa, particularly Somalia and Kenya and the Boko Haram insurgency in West Africa. It is instructive that Somalia did not have a central government for some time due partly to such challenges. There are many examples of the breakdown of state power and authority in the Middle East due to the activities of technology-bolstered terrorist groups such as the Islamic State in Syria (ISIS) and the Levant (ISIL), among others.

National values of social cohesion are very important to the average African state. This is because in many cases, such states are composed of multiple ethnic nationalities resulting from the ways by which colonial powers created many African states by fiat, often without consultation or thought for the effects of heterogeneity on the socio-political stability and development of such states. This is why Madayan [15] argues "in the Third World countries, the issue of (political) stability (has come) to be as important as the issue of democratic change". An untamed mass media and uncontrolled use of ICT (where, for instance, there is no respect for human rights or the sanctity of the state and its government on-line) can easily become detrimental to national political, socio-cultural and economic goals and visions of the state.

ICT also affect African states by discouraging neglect of the primary sectors of the economy where they have comparative advantage such as agriculture while concentrating huge investments in high-tech sectors (such as telecommunica- 
tions) that are controlled by foreign countries who own and control ICT technology. ICT affect African economies by sharply polarizing them and labour markets into the skilled and unskilled; "the employables" and "the unemployables" in the high-tech dominated sectors of the economy which are becoming more popular in Africa. The experiences of South Africa and Ghana that were cited above are instructive.

Information Communication Technology (ICT) has been linked to globalization, which objectives include:

To throw the national economy, now marketized, wide open to the international market which is seen as a global open field for equal players... the globalization campaign sees the world market as confined by many prison walls. Among these are self-reliance, production for the development of the home market and for the consumption of millions of persons rather than for export, any act aimed at protecting the value of the national currency, state trading which is usually not on capitalistic free market terms, any restriction on foreign capital investment, any act aimed at encouraging industrialization in developing countries (such acts being regarded as hostility to agriculture), any tax on agricultural export goods, and any protection of domestic activity by almost any form of trade restrictions-tariff or non-tariff [16].

Paraphrasing Strange [17], Smith aptly summarizes the over-arching negative influences of globalization and ICT on states and governments, particularly Third World states. He argues:

Globalization has social and cultural dimensions... Global communications networks have far-reaching consequences for businesses, governments, educational institutions, voluntary bodies and community groups... The nation state is ...undermined by these forces... Transnational networks of production, trade and finance relegate national governments to "transmission belts" for global capital. World market forces are more powerful than state actions both domestically and in the international arena, so that while state intervention may have increased, the state's effectiveness in providing what markets do not-security, financial stability, law and order, and public goods such as infrastructure-has declined. Global capital imposes a discipline on states, leaving governments only with policy choices that are consistent with a free market. National sovereignty has been displaced by global and regional institutions... [13].

The worst affected states in the scenario painted above are the developing or Third World countries, Africa inclusive. This paper seeks to explore the extent to which public policy can be used as an instrument for regulating and controlling the use of telecommunications by African countries such that state sovereignty would not be unduly compromised and the cultural and economic interests of the people would not be jeopardized through the adoption, deployment 
and utilization of ICT by African countries.

\section{Significance of the Research: Public Policy Driven ICT Development in Africa}

The major significance of this research lies in its attempt to explore the utility of public policy as an instrument both for strengthening and straightening the path of ICT development in pursuit of African values; to strengthen its capacity to serve the purpose of lifting the continent out of its present quagmire; and to assure a brighter future for Africa's younger populations. A public policy-driven ICT development is possible because public policy is what governments choose to do or not to do in the pursuit of specific public goals or purposes be they re-direction, regulation, rejection, renewal, development, consolidation, etc. Thus Dye [18], for instance, argues "public policies may regulate behaviour, organize bureaucracies, distribute benefits, or extract taxes-or all these things at once". Kwankam and Ningo [19] therefore notes that many African countries have not been exploring the possibilities of public policy to address the numerous challenges facing their societies, states and governments to the fullest. In their words:

Policy issues are central to most development efforts, ... (but) in most (African) countries there is a policy vacuum in IT, with only inadequate coverage (if any) being provided from related areas such as telecommunications and the computer industry. The policy aspects of IT therefore need to be addressed, in terms of formulation, dissemination, and implementation. In the absence of clear and enforceable policy, the industry is likely to evolve in a haphazard manner in reaction to uncoordinated external motives, thus allowing improper practices that would impair the growth of enthusiasm for IT... the prospect of a technology with such potential as IT evolving totally unchecked within our (African) countries is disquieting... The rational transfer and application of this technology requires that some guidelines be set down for service providers, distributors of equipment, and end users alike.

This paper aims to help African governments and the African Union, the private sector, policy makers, non-governmental organizations and other stakeholders see the many possibilities for using public policy as an instrument for addressing the challenges and harnessing the opportunities presented by the adoption and utilization of ICT in Africa for the benefit of the continent.

\section{Conceptual Framework: "Cyber Square" and Cyberspace Policy}

The concept of "cyber square" is conceived in this paper to indicate the almost inescapable presence and importance of the internet and associated technologies that promote the convergence of ideas and discourses that underlie relationships in modern personal, corporate and public lives and governance. It is comparable 
to the direct democracy of the Greek city-state's public square or city-centre, where issues of state or public importance were discussed in such a manner that every citizen had the opportunity to make contributions to how the city was governed. "Cyber square" is an idea for which "e-governance" in today's public realm and discourse can be a close substitute or at least, a variant. This is because both concepts which today, are becoming clearer as realities in the public realm, opportunes wide strata of the citizenry to affect, or at least, contribute to modern governance.

According to Habermas [20] and Arendt [21], the public sphere which arose with the rise of the capitalist economy and the bourgeoisie in the eighteenth century provided a melting point for reconciling the differences between public authority and civil society. For Raiti [22], it is surprising that Habermas' "public sphere seldom appears in ICT for development (ICT4D) literature even though the notion of democratization in Africa is nearly ubiquitous" and "technology has been considered a gateway toward a global public sphere". In spite of its many criticisms, Habermas' nostalgic attachment [20] to the debates at French public salons of the early $19^{\text {th }}$ Century has survived and re-echoed as "talk shows" by Livingstone and Lunt [23], as "new ICTs" by Sparks [24] and by Raiti [22] as "the efficacy of mobile telephony" in empowering citizens to contribute to their governments globally including sub-Saharan Africa. Calhoun [25] argues this will lead to rational debate capable of facilitating political deliberation. But the uneducated and property-less classes were ostracized from this bourgeois public sphere which later transformed into a realm of what Arendt termed "tangible freedom", the "site of speech".

In line with the above, Irele has argued that:

The public sphere ... embodied the ideas of a group of people coming together as equals in a private forum, which was distinct both from the public authority of the state and the private realm of the civil society and family life, and was capable of shaping public opinion and opinion and tastes through logical argument, critical analysis and persuasive language. The idea of the public sphere embodied what Habermas calls a principle of "publicness" or "publicity", that is, the opinion of private individuals could evolve into a public opinion through the rational-critical arguments of a group of public-spirited citizens, which was open to everyone as well as free from domination [26].

Just like the determinants of "publicness" and "privateness" that were identified by Benn and Gaius [27], the "cyber square" and its operations can be said to be characterized by access, agency and interest. While access is a description of the level or extent of restriction that can be placed on an activity (an activity that cannot be restricted is public while it is otherwise private), agency seeks to answer the question on whose behalf the action is undertaken or the extent of autonomy of an action. Interest attempts to pinpoint or describe who benefits from an action-the individual, the group involved, the state or some other actors. It is 
a measure of the degree of altruism or selfishness involved in an action.

In reality, access to cyberspace is relatively unrestricted, guaranteeing the widest access to anyone that wishes to utilize cyber technology for specific ends. The cost of entry is also cheaper than other traditional means of engagement with target audiences. Comparing traditional civil disobedience with "cyber civil disobedience", Crosston argues that:

Traditional civil disobedience is a "performance" via visual and physical mediums, while cyber disobedience is essentially a digital performance with difficulty in attributing true ownership of the act... But this new space also has a low cost of entry and regimes will find it difficult to physically control (it). Another distinction is how actors intending to cause wide-scale state damage are a very real cyber threat, while cyber disobedience that does not intend to fundamentally damage the state from cyber-attacks that aspire to is incredibly important but has proven elusive within formal cyber policy [28].

Like the public sphere described above, the "cyber square" of today represents a major domain for a worldwide virtual franchise of ideas on almost every subject that affects the welfare of the global citizen including governance, representation, economy, human rights, livelihoods and a host of other issues that have become relevant to humanity. The "cyber square" does not recognize any physical, social, spatial, political or territorial boundary as it operates in free space and in a world of its own, limited only by technological knowhow and availability of equipment. It is a domain where no ruling tyrant can easily command obedience or impose limits on entry or circumscribe the freedoms of expression that individuals can enjoy for selfish ends without earning public opprobrium.

Therefore, the "cyber square" is gradually becoming a threat to unpopular governments and so-called tyrants who can be easily criticized and made to listen to opposing ideas which they would ordinarily silence through soldiers, guns, bayonets and imprisonment if the contest and the battles were physical. The Arab Spring in North Africa and parts of the Middle East proved this at the end of the first decade of the twenty-first century. This happened most notably in Libya where the use of the internet helped bring Mouamar Ghaddafi's regime to an end. It also happened in Egypt where sustained exchange of information using different modes of telecommunication amongst citizens helped mobilize popular actions that brought Hosni Mubarak's three-decade old government to its knees in less than three weeks in February 2011. Similar actions in 2011 also forced former Tunisian leader Zine Ben Ali to relinquish power and flee the country. Although several governments have now cultivated the habit of blocking or severing internet connectivity to their citizens at critical periods in their countries' histories, this is only a temporary unpopular measure that cannot continue as governments now rely on the Internet and other products of communications technology to conduct official government business through " $\mathrm{e}$ governance". 
The concepts of "cyber square" and cyber space are applicable to this study because many media of telecommunication exist and operate in and through space, which makes them somehow autonomous and, barring temporary governmental clampdowns, affords free entry and exit to whoever has the equipment and technical knowhow to access and utilize them. Also, they are domains that afford larger, almost unlimited extents of freedom and opportunity to individuals and groups to free themselves from the shackles of fellow men, oppressive governments and institutions through self-expression and the definition of identity, whether they are political, economic, cultural, etc in nature. The "cyber square" and cyber space affords today's global citizens the power of virtual existence to give and to receive information (for example, through the information superhighway) that cannot be easily circumscribed. It provides enormous informational powers and opportunities to individuals, groups, states and societies to maximize their opportunities. This is the world to which Africa is welcome.

\section{Africa, Globalization and ICT}

Research and development of new technology is a major characteristic of globalization while Information Communications Technology (ICT) is one of its major features and platforms for its propagation. Today, ICT and globalization have become realities that any country can hardly avoid or do without. As the timeframe for attainment of the Millennium Development Goals (MDGs) ended in 2015, they have been replaced by the new United Nations Sustainable Development Goals (SDGs) for the future, which highlights the importance of ICT to human development and the need to provide humans with universally affordable access to the Internet.

The new SDGs contain the following six ICT-related indicators:

- Proportion of schools with access to computers for pedagogical purposes and proportion of schools with access to the Internet for pedagogical purposes (target 4.a-upgrade education facilities);

- Proportion of youth/adults with ICT skills, by type of skills (target 4.4-promote relevant skills);

- Proportion of individuals who own a mobile phone, by set (target 5.b-enhance technologies to empower women);

- Percentage of the population covered by a mobile network, by technology (target 9.c-increase access to ICT);

- Fixed Internet broadband subscriptions, by speed (17.6-enhance cooperation on science, technology and innovation); and

- Proportion of individuals using Internet (17.8-enhance the use of enabling technologies, particularly ICT [29].

In the reckoning of International Telecommunications Union, the above specifics are attributable to the fact that, while data are often available to measure ICT infrastructure and adoption, data on other topics, such as ICT in education, skills, and gender equality is, where available, are often less substantial [29]. This is true of Africa where data availability, gender and religious biases still affect development research. 
Although the world is now a global village, the question of a country or region's strength and ability to harness the gains of globalization and appropriate its benefits for development depends on several factors which include access to and versatility of its citizens in ICT. Relating the above to Africa, one can safely infer that ICT in Africa have come with mixed outcomes or results.

The ascendancy of ICT and its strategic relevance to the continent's economic recovery from centuries of exploitation and marginalization is regarded as Africa's "fourth industrial revolution". There are high expectations based on the rising ICT profiles of some African countries like South Africa, Nigeria, Morocco, Egypt and Kenya and the overall bright continental outlook. Taking Nigeria, the most populous black nation worldwide as an example, with government's political will that resulted in the licensing of three GSM operators in 2001, a fourth in 2002 and the privatization of the incumbent parastatal NITEL in July 2006, Nigeria passed Egypt and Morocco in 2004 to become second to South Africa in mobile market coverage and more than fifty (50) companies providing fixed telephony services in addition to privatized NITEL, the second national operator (SNO) [29]. Yet, the country only reached just a quarter of its estimated market potential. Internet services are also booming in different countries with fixed telephony services and a vibrant young population in most African countries. As Wentworth [30] explains, internet connectivity across the continent grew from around $7 \%$ of the population with Internet access in 2008 to over $20 \%$ with Internet access in 2015.

In spite of the above, however, the benefits have not been generalized or evenly distributed across African countries and regions. For example, the figures cited by Wentworth [21] above showed that about $80 \%$ of the African populations were yet to enjoy Internet services as at the time. The Internet Society [31] summarized the overall picture succinctly. According to it:

Internet penetration levels are about $20 \%$ and rising. Mobile subscriptions are just shy of $70 \%$, and mobile broadband access accounts for more than $90 \%$ of Internet subscriptions. But the aggregate indicators mask glaring disparities. At the high end of the spectrum, countries such as Morocco enjoy penetration rates above $50 \%$, but at the other end are countries with penetration rates of below $2 \%$, and the majority of countries have internet penetration of less than $10 \%$ (well below the $20 \%$ threshold that has been found to be critical for countries to reap the economic benefits of broadband investment).

The above shows that ICT have not led to the same outcomes in different African countries. Next, we take a brief look at the benefits and challenges of ICT adoption in Africa.

\section{Information Communication Technology (ICT) Policies in Africa}

A national information communications technology policy can be defined as an 
integrated set of principles, norms and ideals that are meant to guide ICT objectives, development, adoption, content and usage within a state. Because every state has historically specific conditions and needs which must have been agreed upon by the people (something like directive principles of state policy), a state's ICT policy should locate its raison detre within the historical, political, economic and cultural situations in which it is to be adopted and the challenges it is to address.

The first and arguably the most critical challenge confronting the development of ICT in Africa, which also has a bearing on other problems of ICT development in the continent is the relevance of Africa's national ICT policies to the African situation. For example, ICT policies of African states should interrogate the objectives of ICT adoption and utilization at this critical historical junction where Africa is confronted with the realities of unrestrained capitalist globalization with its negative implications for weak economies such as those of Africa. African ICT policies should question the level or degree of political will that African governments demonstrate in making ICT serve the political, economic and cultural needs of Africans; and they should enquire into the possibilities of creating digital cultural spaces through ICT to promote African cultures, values and ways of life rather than those of the creators (or manufacturers) of ICT technologies which have little or no respect for African values and worldview but rather disparage or seek to subvert them.

Lasswell [32] demonstrates that in many post-colonial states including Africa, the development of national communication structures and organizations in the immediate post-independence era did not encourage political inclusion but pursued a psychology of political exclusion against numerous ethnic nationalities estranged from political power. Many of Africa's political leaders misused communication to emphasize the primacy of political power, to further the "strategy of awe" to their political opponents and to transmit a "deliberate and unpremeditated message of modernity, determination and self-confidence" [32] to those for whom the image of their society had been tarnished by alien colonial and imperial subjugation [33]. They also failed to utilize communication to entrench and deepen the democratic culture, ethos and ideals of national integration or broad-based political development. No wonder many of such governments fell to military rule for various reasons.

Given that many African countries failed to maximize the benefits of communication for national development in the immediate post-independence era, they should not repeat that error with a second opportunity provided by ICT. For this reason, we now attempt to conduct a simple assessment of ICT adoption in Africa by examining its consequences or outcomes of its adoption by African states. Thereafter, we prognosticate on how African states can leverage on ICT for their next stage of development with the aid of purposeful ICT policies.

\section{Benefits and Constraints of ICT Adoption in Africa}

The embrace of ICT in Africa has contributed to the spread of ideas that have 
re-shaped and are still reshaping the political, economic, business and governmental landscapes as well as the security architecture of Africa. Whether for good or bad, it may be said that the embrace of ICT will ensure that Africa cannot be the same old continent again. ICT have brought several salutary results to Africa.

First, ICT have succeeded in linking the continent to the rest of the world through high bandwidth submarine fibre optic cables linking Africa (from Nigeria and other countries) to Europe through a 7000 kilometre-long distance from Portugal. This put an end to decades-long isolation of Africa from other continents [34]. It is expected to affect positively, every facet of African life.

Second, ICT has contributed towards deepening and entrenching democracy in Africa by providing media for citizen actions to stand up against authoritarian and autocratic governments. The governments of such countries characteristically shut down communication networks at critical periods in their countries' histories, sometimes for selfish political reasons. Examples of countries where this happened include Uganda, Chad, Republic of Congo, Zimbabwe, DRC, Burundi and even Ghana with its democratic credentials that makes it to be regarded as a model of democracy on the continent [35]. Others in this category include Tunisia under former President Zine Ben Alli and Egypt's Mubarak who imposed media blackouts in the wake of the Arab Spring in 2011 but were removed by popular actions powered mainly through the use of ICT. Similar incidents also occurred in several countries of the Middle East at the end of the first decade of the twenty-first century. In spite of governments' actions, activists utilized the internet and social networks to inform and mobilize people for the defence of democracy in such countries, thus bringing to pass Raiti's [22] expectation that African tele-centers could become sub-Saharan Africa's versions of the French salons.

In order to appropriate the benefits of ICT to the fullest, however, there is a need for education and literacy, and Habermas was also emphatic on this point. In making the point that the literature often overlooks these requirements for ICT usage, Raiti [22] becomes suspicious that most western and some African literature on democratization (such as Berger, 2002) [36] may be merely an extension of academic and political imperialism even as Africa struggles to stabilize and consolidate her tottering democracies. Therefore, Raiti queries whether democracy is an end goal in itself or a means to an end? He queries the ethical foundations of the desire of corporations and their shareholders to reap financial benefits especially from rural Africa by making telephony and ancillary services available to the rural poor without fulfilling the requirements for doing so. These include the "critical junctures" of literacy and growing education. Thus, more than education without ICT can induce "schooling without learning", the provision of ICT to the rural folk without literacy, education and nationalistic orientation can induce misguided zeal. This scenario has escalated the threat of terrorism globally and especially in Africa as ICT devices become increasingly available to dispossessed, disenfranchised, displaced, disoriented and disgruntled 
individuals and groups. Both are potentially catastrophic and unfortunately, represent the reality in Africa today. Interrogating these issues is directly related to ICT for development on the continent.

Third, if current growth rates are sustained and built upon, ICT will likely help to raise Africa's productivity factor in the near future. Projections by GSMA, an association of mobile telephone operators suggest that by 2020 , there will be in Africa more 700 million smart-phones in Africa, more than twice the projected number for North America and close to the projected figure for $\mathrm{Eu}$ rope. Mobile telephony is expected to contribute $8 \%$ to Africa's GDP by 2020 while the Internet could potentially contribute $10 \%$ of GDP to African countries by 2025 [37].

Fourth, ICT is already helping to contribute to the ease of doing business in Africa, thus bringing more investors into the continent provided the issues of corruption and the power sector are well handled and government policies create investor-friendly environments in Africa. Already, e-commerce is growing while mobile financial services are on the rise, showing signs of a better business environment in Africa. Within these, there is the probability of finding better markets for Africa's resources, finding better uses for their raw materials as well as greater capabilities to turn them into semi-finished products with higher values. Overall, digitization efforts will bring more businesses and governments online in Africa and the economy will improve.

In spite of the benefits, however, there are numerous challenges confronting the development of ICT which may affect the continent's chances of reaping maximum benefits from its development in Africa.

First is the challenge of the relevance of Africa's national ICT policies to the African situation. As Momoh [38] argues, "to combat an endemic psychology of "under-developed man and culture", should be one of the main thrusts of an informed national communication policy in an African country". He opined further that "it is indeed crucial that any enlightened national communication policy in an African society ought to have the goal of decolonization as its central focus". Another observer makes the point more clearly and more forcefully when he argues that:

If, in the process of acquisition of modern technology and scientific outlook that goes with it, people of developing countries acquire and perpetuate a sense of inferiority and loss of confidence vis-à-vis current sources of technology, the gap between developing and developed nations will continue to widen [39].

This is a warning to African countries and their governments not to see the embrace of ICT as an end in itself or a solution to the many problems of Africa and its peoples. Rather, African countries should see it as a means to the end of dependency on the West for virtually everything. This includes but is not limited to technologies for exploiting Africa's natural resources, cultural resuscitation and renewal, entrenchment and consolidation of democracy as well as urban 
planning, growth and development. The critical question is "what are the goals and objectives of Africa's ICT policies?" and "who is and who is not consulted in their drafting and approval?" ICT policy drafting and adoption in Africa should not be the exclusive preserve of government, the bourgeoise capitalist entrepreneurs and representatives of foreign capital alone. It should adopt a bottom-up process involving collaborative governance that is reminiscent of the new network society that we now live in.

Second, although African governments have adopted the multi-stakeholder approach towards ICT governance and is yielding result, they should demonstrate greater commitment to ICT development through greater funding, more collaboration with stakeholders, better regulation that recognizes no sacred cow (of operators) and other oversight functions to stabilize the sector for sustained growth and benefits. African governments will need more political will, commitment and practical action to meet the needs of the continent's growing ICT market that is populated mainly by young people. According to the Internet Society [31], "Africa needs a coherent strategy for capacity development at all levels, and this strategy needs to look first at ICT as a discipline and secondly as a cross-cutting enabler of other disciplines".

Third, there is the challenge of increased cybercrimes and privacy concerns but this is a global rather than an exclusively African problem. As Serracino-Inglott [40] and Crosston [28] inform, there has been a remarkable lack of consensus on establishing unified norms of cyber behaviour and the global political system is seen as having utterly failed to protect civilians from cyber crimes, attacks and abuses of human rights online. In a development that shows the weakening powers of the state globally, cyber vigilantes acting self-righteously within self-imposed boundaries of morality and operating outside of the law now take upon themselves the duty of cyber protection and cyber crime fighting.

Fortunately in a show of determination and solidarity, the African Union (AU) has developed a Convention on Cyber Security and Personal Data Protection aimed at committing member states to establish legal frameworks for e-transactions, data protection and punishment of violators [31]. The AU is also involved in AXIS and dot Africa projects to combat cyber abuses while it is including the control of cybercrimes and privacy concerns in the continent's fifty-year plan, 2063 Agenda to secure the cyberspace. The continental organization also has an African Internet Governance Forum to address several cyber security related issues [40]. However, since experience shows that many international protocols and agreements are breached at will once there is no monitoring organ to enforce compliance and there are no penalties for default, it is recommended that the AU should empower a committee to monitor compliance and impose fines on defaulters.

Fourth is the challenge of flagrant abuse of human rights on digital media platforms such as face book, twitter, whatsapp, etc especially when contested political, social and economic prizes and value allocations such as elections are involved. Although digital media platforms have the capacity to serve positive 
purposes such as checkmating dictatorial tendencies in political leaders (such as happened during the Arab Spring around year 2011), several developments have combined to raise the issue of control of digital media platforms to the front burner of public discourse using the instrumentality of the United Nations to advance common understanding and solutions to online abuse of human rights. Examples include the use of online media to discredit political opponents and spread hatred in speech and action during the Nigerian presidential elections of 2015. That election was eventually lost by the Peoples Democratic Party (PDP) that had ruled the country for four unbroken terms totaling sixteen years.

However, human rights abuses online are being addressed at the continental level through an aggregation of concerned organizations who launched the African Declaration on Internet Rights and Freedoms in 2014. Its objectives include the promotion of online respect for human rights in Africa; openness in Internet and ICT policy making and implementation in Africa [40]. Again, there is need for collaborative efforts by all stakeholders including network operators, network engineers, industry players, civil society, individual and corporate end users. Governments must be involved because they have the instruments of ensuring compliance, redress and punishment in cases of breach. However, governments, intelligence agencies, criminals and corporations are also involved in cyber surveillance; hence the need for a collaborative approach to cyber-right watch in order to have an Internet of opportunities rather than of apprehension. How that can be achieved can be the subject of another research.

Other challenges to ICT utilization in Africa include inadequate and aging infrastructure that causes congestions; the need for funding to upgrade equipment to desired levels; lack of basic infrastructure like access roads and electricity to drive the ICT revolution and the high cost of ICT services that raises the challenge of affordability for Africa's teeming poor populations. On cost, for instance, the Internet Society [40] reports that "currently ... users in Africa pay up to 30 or 40 times more for Internet access than their peers in developed countries". Although Africa currently has over 30 Internet exchange points (IXPs), each country and each of the five geographical regions should have at least one to catalyze the build-out of terrestrial infrastructure in order to make access to the Internet faster and cheaper for everyone [40]. Achieving this is a question of funding.

The African ICT space is dominated by foreign competitors whose practices may not promote the national and indigenous values of their host countries such as local language content. And African governments sometimes shut down ICT facilities for punitive political purposes or values. Given that many African investors shy away from the ICT sector, there is therefore the challenge of how to rein in Africa's entrepreneurs so they can invest in ICT as this may help drive the objectives of national ICT policies faster. There is also a need to bring into the ICT threshold many Africans who currently operate in the informal sector.

Many of the challenges of ICT adoption and utilization in Africa can be addressed through dedicated national ICT policies, especially if the drafting and 
implementation of such documents follow the collaborative, bottom-up model of public policy making and implementation. The collaborative or multi-stakeholder model has prospects for group thinking (or "thinking together") with unlimited capacities for problem-solving among stakeholders in a mutually-reinforcing manner. Although the challenges are enormous, the collaborative model has a capacity to throw up useable new heuristics that may lead to problem-solving as individuals and groups work and think together over common problems. For example, the ICT industry in Kenya is now practicing the infrastructure-sharing policy that allows several networks to use a single mast [41], a practice that can be experimented in other countries.

Different African countries have various qualities and features several high performers in the ICT, e-commerce and e-entertainment and ICT funding sectors whose experiences can be leveraged upon to promote Africa's ICT development. For instance, while Nigeria has the best ICT market potential in the continent, South Africa has the best ICT infrastructure and education while Kenya has a very good ICT policy. Again, some high performers in Africa's ICT and allied sectors include South Africa's MTN and M Pesa mobile money; Nigeria's Globacom and the Jumia Group; Kenya's iHub and Tanzania's Savannah Fund Investment. African must leverage on the experiences and strengths of these and many other continental players not only to develop the ICT sector further in Africa, but also to indigenize or "Africanize" it. However, this cannot happen in a vacuum.

To achieve the above, Pejout [12] has outlined four priorities while there is a gender perspective [42] to the enhancement, acceleration and "Africanization" of the second new economy in the continent. An expansion of Pejout's priority areas in line with current realities would possibly include the following:

1) Building and enhancement of appropriate telecom/IT (to widen and improve coverage) and other basic infrastructure (like electricity, access roads, etc) without which ICT cannot thrive;

2) Building of appropriate institutions to facilitate fair competition among players; a strong and efficient regulatory regime to curtail operator abuses and excesses; and the democratization of access by building more Internet public access and training points. This can be achieved through collaboration with local, national and international stakeholders;

3) By deliberately creating a "second new economy" or ICT industry plan to improve Africa's broadband infrastructure network and to inculcate the digital culture into Africa's educational systems. The New Partnership for Africa's Development, governments at various levels and the philanthropic private sector and non-governmental organizations took up this challenge in the past and got results; now the challenge is to build on its achievements for future expansion. Also, the e-schools initiative is succeeding as many pupils in Africa are already computer literate. Already, there are many e-learning programmes in Africa's schools while many examination bodies like Nigeria's Joint Admissions and Matriculation Board (JAMB) are gradually shifting to e-examinations. In light of the 
ICT revolution, Babalola [43] argues, it has become clear that without ICT/digital education, Africa's children may get schooling without learning. Such an education would not prepare its beneficiary for gainful employment;

4) Consequent upon the polarization of Africa's labour market by the ICT revolution, there is a need to prevent unemployment from rising higher by facilitating multi-layered skills development strategies to enable many Africans (even with the basic skills) to find opportunities for gainful employment in the new, ICT-led economy, from which they can develop their skills further;

5) Telecommunication serves as a catalyst in human and social development by providing timely access to data and information. Therefore, access to ICT can be regarded as a determinant feature of gender relations, women's empowerment [42] and productivity. Given that women constitute over 50\% of Africa's 1.2 billion population [32] and that they are an indispensable force for economic advancement in many African cultures, the gender perspective must be brought to bear on ICT planning and development in Africa in order to reap its fullest benefits;

6) Finally, Africa's ICT development must be public policy-driven for several reasons. These include the need to direct it towards meeting African rather than foreign needs in terms of acquisition, domestication, financing, costing and democratization for the sake of sustainability, application or utilization to address Africa's high impact development priority areas rather than attempt to catch up with the developed world who in any case, are not waiting for any region to catch up with them. Policy must also address regulation, local control and ownership, coordination, harmonization (or at least, integration) and encouragement of synergy in ICT development between the public and private sectors of African economies. While the public sector can provide mainly the legal and regulatory environments for ICT development in Africa to address the continent's unique challenges, the private sector can provide funding and expertise to drive the process of ICT development smoothly with an eye for quality service, affordability and guided control to avoid inefficiencies as much as possible.

\section{Research Contributions, Innovation and Limitations}

The major contribution of the research is its emphasis on the many ways in which all stakeholders in ICT development in Africa can cooperate not only to "domesticate" ICT adoption and usage but also to enhance its benefits to Africa using the instrument of public policy. Its innovation lies in its conceptual framework using ideas of the "cyber-square" and "cyberspace policy" and linking these with the modern utility and reality of Jurgen Habermas' concept of the public sphere and its significance for liberal, representative democracy that most nations practice today. It is particularly relevant to the African political enterprise where sit-tight regimes continue to hold sway in many countries ostensibly with an air of invincibility. The deployment of ICT in the cyber-square extends the frontiers of political communication in liberal democracies with the increasing use of electronic and digital media to register political dissent, embark on 
cyber protests and to influence voters during electoral campaigns. This means governments alone no longer hold all the aces where political expression is concerned.

The main limitations to the study are its limited tri-disciplinary foundations (limited as it is to political science, public policy and philosophy) rather than a multidisciplinary approach to the development of ICT for development (ICT4D) which Raiti [22] canvasses. However, research is continuous and this effort can be improved upon by introducing fresh perspectives from other disciplines like sociology, mass communication and security studies. Such new perspectives may constitute areas for further research into ICT and Africa. The second limitation is its greater reliance on secondary than primary data. On the first limitation, the research can be seen as an improvement on existing monolithic However, this does not impact negatively on the findings of the study because the author had many opportunities to cross-check facts and data that were used for the study.

\section{Conclusion}

This paper has examined the challenges and prospects of the Information Communications Technology (ICT) revolution against the historical backgrounds to globalization in Africa. It identifies the ICT revolution as a consequential extension of capitalist development that no country can ignore. It therefore argues that in spite of the disadvantaged historical political and economic positioning of Africa vis-à-vis the developed world who are the custodians of most forms of modern technology, African countries can still latch on to the ICT revolution to take an economic leap forward in the historical future. The paper recommends several means of achieving this including the adoption of collaborative synergy in ICT policymaking and implementation at the local, national and international levels. This means such approach must necessarily involve all stakeholders in order to reap the fruits ICT for Africa's economic, political and cultural leap forward.

\section{References}

[1] Mbeki, T. (2003) Characteristics of South Africa's First and Third World Economies. In: Padayachee, V., Ed., A Political Economy of Africa, Routledge, London and New York, 231-244. https://books.google.com.ng/books?isbn=1136989072

[2] Baudry, P. and Sowa, N.K. (1994) Labour in an Era of Adjustment: The Case of Ghana. In: Killick, T., Ed., Development and Economics in Action: A Study of Economic Policies in Ghana, 2nd Edition, Routledge, London and New York, 234-287.

[3] World Bank (2007) Ghana: Meeting the Challenge of Accelerated and Shared Growth. Volume I, World Bank Report No. 40934-GH, World Bank, Washington DC.

http://documents.worldbank.org/curated/en/200461468031469957/pdf/Pages0from 040915403volumes0ER01GH13.pdf

[4] Killick, T. (2010) Development and Economics in Action: A Study of Economic Policies in Ghana. 2nd Edition, Routledge, London and New York, 234-287.

[5] The World Bank (2004) Strategic Framework for Assistance to Africa: IDA and the Emerging Partnership Model. The International Bank for Reconstruction and De- 
velopment/The World Bank, Washington DC, 6.

[6] Kiely, R. (2010) Rethinking Imperialism. Palgrave Macmillan, New York, 184. https://doi.org/10.1007/978-1-137-08870-3

[7] Odedra, M., Lawrie, M., Bennett, S. and Goodman, S. (1993) Sub-Saharan Africa: A Technological Desert. Communications of the ACM, 36, 25-29.

[8] Zwangobani, E. (1987) Communications for Development: A Developing Country Perspective. Conference Proceedings of Africom 87, Computer Society of Zimbabwe, Harare.

[9] Brender, A. and Pisani, F. (2004) La Nouvelle Economie Americaine. Economica, Paris. http://www.cepii.fr/PDF_PUB/em/2010/em2010-02.pdf

[10] Milkman, R. and Dwyer, R.E. (2002) Growing Apart: The "New Economy" and Job Polarization in California, 1992-2000. University of California Institute for Labour and Employment, e Scholarship Repository, University of California, Oakland. http://escholarship.org/uc/item/9k208732

[11] Artus, P. (2000) Nouvelle Economic, Nouveaux Problems. In: Le Cercle des Economists, Esperances et Menaces de la Nouvelle Economie, Descartes and Cie, Paris, 21-42.

[12] Pejout, N. (2010) Africa and the "Second New Economy": How Can Africa Benefit from ICT for a Sustainable Socio-Economic Development? In: Padayachee, V., Ed., The Political Economy of Africa, Routledge, Oxon and New York, 231-244.

[13] Smith, B.C. (2009) Understanding Third World Politics: Theories of Political Change and Development. 3rd Edition, Palgrave Macmillan, Hampshire and New York, 102.

[14] Fashek, M. A Nigerian Reggae Music Star Sang This over Two Decades Ago.

[15] Madayan, R. (2014) The New Al-Qaeda in the Levant and North Africa: The Rebirth after Bin Laden's Elimination. The 13th International Conference of Africanists with the Theme "Society and Politics in Africa", Moscow, 27-30 May 2014, 8.

[16] Toyo, E. (2000) Background to Globalization. The Academic Staff Union of Universities Educational Publication Series No. 2, Ibadan, 18.

[17] Strange, S. (1996) The Diffusion of Power in the World Economy. Cambridge University Press, Cambridge.

[18] Dye, T.R. (2005) Understanding Public Policy. 11th Edition, Pearson Education Inc., Pearson, 1.

[19] Kwankam, S.Y. and Ningo, N.N. (1997) Information Technology in Africa: A Proactive Approach and the Prospects of Leapfrogging Decades in the Development Process. http://www.isoc.org/inet97/proceedings

[20] Habermas, J. (1989) The Structural Transformation of the Public Sphere: An Inquiry into a Category of Bourgeois Society (Trans. by Burger T. with the Assistance of Lawrence F.). Polity Press, Cambridge, 161.

[21] Arendt, H. (1958) The Human Condition. The University of Chicago Press, Chicago, 50-58.

[22] Raiti, G.C. (2006) The Lost Sheep of ICT4D Research. Massachusetts Institute of Technology Information Technologies and International Development, Vol. 3, 1-7.

[23] Livingstone, S. and Lunt, P. (1994) Talk on Television: Audience Participation and Public Debate. Routledge, London. https://doi.org/10.4324/9780203310243

[24] Sparks, C. (1998) Is There a Global Public Sphere? In: Thussu, D., Ed., Electronic Empires. Global Media and Local Resistance, Arnold, London, 108-124. 
[25] Calhoun, C. (1992) Introduction: Habermas and the Public Sphere. In: Calhoun, C., Ed., Habermas and the Public Sphere, MIT Press, Cambridge, 1-50.

[26] Irele, D. (1999) The Public Sphere and Democracy. Viewpoint: A Critical Review of Culture and Society, Vol. 1, 52-64.

[27] Benn, S. and Gauss, G. (1983) Public and the Private: Concepts and Action. In: Benn, S. and Gauss, G., Eds., Public and Private in Social Life, St. Martin's Press, New York, 7-11.

[28] Crosston, M. (2017) The Fight for Cyber Thoreau: Distinguishing Virtual Disobedience from Digital Destruction. In: Korstanje, M.E., Ed., Threat Mitigation and Detection of Cyber Warfare and Terrorism Activities, IGI Global, Hershey, 198-219. https://doi.org/10.4018/978-1-5225-1938-6.ch009

[29] International Telecommunications Union (ITU) (2016) Sustainable Development Goals and the Internet: Measuring the Information Society Report. Internet Platform/Digiwatch in Partnership with Internet Society, Geneva. https://digitalwatch.giplatform.org/processes/sustainable-development-goals

[30] International Telecommunications Union (ITU) (2016) ICT Facts and Figures 2016. http://www.itu.int/en/ITU-D/Statistics/Documents/facts/ICTFactsFigures2015.pdf https://www.internetworldstats.com

[31] Wentworth, S.S. (2015) The Internet Needs Africa as Africa Needs the Internet-A Speech to the African Union.

[32] Internet Society (2015) Internet Development and Internet Governance in Africa. http://www.internetsociety.org/doc/internet-development-and-internet-governance -africa

[33] Lasswell, H.D. (1977) Building Political Communication: The Signature of Power and Environment. In: Daniel, L. and Lyle, M.N., Eds., Communication Research: $A$ Half Century Appraisal, The University Press of Hawaii, Honolulu, 280-294.

[34] Nnaemeka, T. (1989) Issues in National Communication Policy: Parameters of Theory and Experience. In: Nnaemeka, T., Uvieghara, E. and Uyo, D., Eds., Philosophy and Dimensions of National Communication Policy, Vol. 1, Centre for Black and African Arts and Civilization, Lagos, 1-9.

[35] The Guardian (2016) Africa's Top 10 Tech Pioneers: "We Have Become an Internet-Consuming Culture".

http://www.africaontherise.com/2016/07.africa's-top-10-tech-pioneers-we-have-bec ome-aninternet-consuming-culture/

[36] Berger, G. (2002) Theorizing the Media-Democracy Relationship in Southern Africa. Gazette: The International Journal for Communication Studies, 64, 21-45. https://doi.org/10.1177/17480485020640010201

[37] The Guardian (2016) Can the Internet Reboot Africa? https://www.theguardian.com/world/2016/jul/25/can-the-internet-reboot-africa

[38] Momoh, T. (1989) A Framework for National Communication Policy. In: Nnaemeka, T., Uvieghara, E. and Uyo, D., Eds., Philosophy and Dimensions of National Communication Policy, Vol. 1, Centre for Black and African Arts and Civilization, Lagos, 10-23.

[39] Banani, A. (1977) Towards a National Communication Policy for Iran. In: Teherania, M., Hakimzadeh, F. and Marcello, L.V., Eds., Communications Policy for National Development, Routledge and Kegan Paul, London, 279.

[40] Serracino-Inglott, P. (2013) Is It OK to an Anonymous? Ethics and Global Politics, 6, 220. https://doi.org/10.3402/egp.v6i4.22527

[41] Ekiti State of Nigeria (2011) Ekiti State Gender and Development Policy. BIGIF/ 
Kingdom of the Netherlands, Ado-Ekiti, 11.

[42] Babalola, J. (2010) Transition from Chalkboard to Digital Whiteboard: Keeping pace with Challenges of 21st Century Learning Technologies in a Developing Economy. His Lineage Publishing House, Ibadan, 5.

[43] Worldstat (2017) Sex Ratio in Africa. http://en.worldstat.info/Africa

Submit or recommend next manuscript to OALib Journal and we will provide best service for you:

- Publication frequency: Monthly

- 9 subject areas of science, technology and medicine

- Fair and rigorous peer-review system

- Fast publication process

- Article promotion in various social networking sites (LinkedIn, Facebook, Twitter, etc.)

- Maximum dissemination of your research work

Submit Your Paper Online: Click Here to Submit

Or Contact service@oalib.com 